\title{
Changes in the Content of Music Education in Primary Schools
}

\author{
Rasa Jautakytè
}

\begin{abstract}
After the restoration of Lithuania's independence and the declaration of the Lithuanian school reform idea, a goal was set to restructure the Soviet content of education and make universal human values the foundation of the process of education, with due regard to principles of national identity, integration, differentiation, and creativity. This article focuses on the changes in teaching music in primary schools during education reform in Lithuania when two weekly lessons of music were introduced, two alternate syllabi were developed, and new textbooks were published. This study analyses the changes in the content and methodology of music education, based on fostering pupils' creative abilities and skills of artistic expression as well as on education of the individual as a cultured user of artistic values.
\end{abstract}

Keywords: music education, primary school, Lithuania

\section{Introduction}

The national school traditions cherished in the Republic of Lithuania were seriously undermined by the genocide carried out by the Soviet administration in the post-World War II years. After the majority of the most significant national and global cultural values were replaced by Soviet culture substitutes, the cultural foundation of Lithuanian schools also changed. School almost ceased to be a fosterer of national culture continuity and educator of national awareness and failed to resist the negative trends of authoritarianism. A shortage of alternative ideas and different systems of education instilled indifference to cultural and spiritual values.

During the Soviet era, the role of academic subjects in the humanities and arts diminished greatly. At school, only one music lesson per week remained, religious music was removed, and ideology was imposed on music. Education acquired a purely academic character oriented towards providing children with knowledge. Therefore, music was no longer taught as a subject of art, but more like the natural sciences with attention focused on the most important things such as knowledge, abilities, and skills. Academic subjects were taught in isolation from each other, and their content was not related to Lithuanian ethnic culture or the sociocultural context of a specific era. ${ }^{1}$

1 Ž. Jackūnas, 'Lietuvos mokykla sovietizacijos pinklese' [Lithuanian school in the Sovietisation trap], Lietuvos kultūros bükle [The situation of Lithuanian culture], Vilnius, Standartų leidybos Vilniaus spaustuve, 1990, pp. 109-110. 
In 1990, as the Lithuanian independence restoration movement began and fundamental changes occurred in political life and socio-economic conditions, the need emerged to carry out education reform, to reconstruct the education of the young generation. The theoretical foundation of Lithuanian education reform was based on ideas of preservation and enhancement of national identity, fostering national cultural traditions and forming moral values. The importance of creating national identity was accentuated with the 'Law on Education' that indicated that education shall be based on humanistic, national, and global cultural values. ${ }^{2}$

The principal aim of "new era" education was "independent and creative individuals, who reveal their abilities as early as at school". ${ }^{3}$ In Lithuanian education, school was meant to educate according to each pupil's intellectual capabilities, general and artistic competences, and culture, so that each pupil saw the process of learning as a meaningful and motivated activity. Pupils had to be active in lessons and interpret analysed material in the context of their own experience, interests, and sociocultural lives. An objective emerged: restructure the content of education and change the style of relations at school on the basis of democracy and humanism, eliminate autocratic communication, and build the process of education on common human values with due regard to principles of integration, differentiation, and national identity.

This study focuses on changes in the content and methodology of music education in primary schools in the context of education reform implemented after regaining independence.

\section{Restructuring musical education in primary schools as part of education reform}

Following the declaration of the new Lithuanian school concept, restructuring of arts education began immediately. Before education reform, schools cared mainly about artistic expression, but new requirements orientated the teaching of art subjects towards fostering pupils' creative abilities and the education of the individual as a cultured user of artistic values. ${ }^{4}$ In 1994, the draft of the General Curricula was made public, and in 1996, the main document that regulated the content of education in comprehensive schools, the General Curricula, was published. It stated that "the most important aim of arts education was to develop pupils' creative, spiritual, and physical powers; to provide them with artistic and aesthetical competences and the fundamentals

2 Lietuvos Respublikos švietimo istatymas [Law on Education of the Republic of Lithuania], Vilnius, Leidybos centras, 1991, pp. 1.

3 Lietuvos švietimo koncepcija [Lithuanian Education Concept], Vilnius, Leidybos centras, 1992, pp. 1.

4 Ž. Jackūnas, 'Meninio ugdymo vieta integruoto mokymo sistemoje' [The place of artistic education in the integrated teaching system], in V. Matonis (ed.), Šiuolaikinès meninio ugdymo koncepcijos [Contemporary conceptions of artistic education], Vilnius, Enciklopedija, 2000, pp. 183-191. 
of moral, social, cultural, and civic maturity; and to educate a sensitive, thinking, creative, and insightful perceiver and active user of art." ${ }^{5}$ In the general curricula, a musical education syllabus for national schools was created, a totally different structure based on the traditions of global cultural heritage. Soviet ideology was abandoned, education of ethnic values was enhanced, and the content of education and methods were improved. At primary school, two weekly music lessons were introduced, even if they continued to be taught by non-specialists. Previously-used textbooks were not acceptable, and teachers had to manage without teaching aids for several years. From 1995 to 2000, two textbooks of music for primary school were published - Lakštutė [Nightingale] by Vida Krakauskaitè and Muzika [Music] by Eirimas Velička.

The first Education Standards that appeared along with the General Curricula was a new education regulations document. Most teachers considered the document an attempt to create centralised directives on what to do and how to do it and questioned its implementation and the probable additional workload for teachers. However, teachers soon recognised the advantages of the education standards, which became one of the main documents for organising musical education at school. Many music textbooks and teaching manuals appeared, making it easier for teachers to develop individual syllabi for a specific school or class, integrate the content and methods of music and other subjects, and assess pupil abilities and achievements. After evaluating the changes in education at comprehensive schools and the comments and proposals of teachers in 2003, a new version of the General Curricula and Education Standards in Lithuanian Comprehensive Schools was approved. The document basically completed an important stage in restructuring the content of education in comprehensive schools. ${ }^{6}$

Restructuring musical education in Lithuanian schools was based on advanced concepts of musical education, developed and introduced by Eduardas Balčytis. ${ }^{7}$ The principal characteristics were complex teaching ideas in which Balčytis argued that musical education based on a single specific musical activity did not allow the manifestation of a child's varied musical abilities. Therefore, he emphasised the significance of singing, listening to music, and playing a musical instrument. Activities were closely interrelated and accounted for a homogeneous system of musical education. A complex structure of the music teaching process complied with the specificity of primary and secondary schools and children's ages and also provided opportunities for

5 Lietuvos bendrojo lavinimo mokyklos Bendrosios programos ir išsilavinimo standartai [General Programs and Education Standards of Lithuanian comprehensive school], Vilnius, Leidybos centras, 1996.

6 R. Girdzijauskiené, 'Muzikinio ugdymo standartų taikymo pradinèje mokykloje ypatumai' [The pecularities of realization of music education standarts in primary school], Tiltai [Bridges], vol. 33, 2006, p. 31.

7 E. Balčytis, Muzikinio ugdymo Lietuvos bendrojo lavinimo vidurineje mokykloje sistema [System of music education in Lithuanian comprehensive school], PhD diss., Lithuanian Academy of Music and Theatre, 1993. 
unfolding their varied abilities and inclinations. It led to consistent and versatile musical education based on different forms of music making, comprehensive musical ear training, and performing and perception, allowing the teacher to independently and thoroughly differentiate and individualise work based on pupils' musical abilities and inclinations. Pupils were provided with conditions that enabled them to manifest themselves in their favorite fields. Balčytis enriched musical education by replacing one-sided theoretical teaching with teaching closely related to pupils' musical activities. ${ }^{8}$

Vida Krakauskaite was one of the first authors of the reformed music syllabus and music textbooks for primary school. She had been developing music teaching methodology and improving it in her work with pupils since 1960. From 1995 to 2000, she published her authorial syllabus ${ }^{9}$ and the textbooks Lakštute [Nightingale], ${ }^{10}$ still used by most primary school teachers. Krakauskaitës music teaching/learning system was based on ethnicity and the complex character of music teaching activities - their varieties, techniques, and forms. The content of music education was based on Lithuanian folk songs whose structure, melodies, and rhythms were appropriate for primary school pupils. Much attention was paid to Lithuanian-composed songs and instrumental music. Krakauskaite’s methodology was closely related to relative solmisation and Carl Orff's rhythm education system. Her innovation was the interrelation of music teaching with moral education and other academic subjects - Lithuanian, reading, and art lessons. Even though Krakauskaite considered refusal of theoretisation to be one of the principles of her methodological system, she sought to provide children with theoretical knowledge of music. Content of education included provision of different kinds of knowledge - teaching notation, explaining the characteristics of sound, and training the skills of music making and singing. ${ }^{11}$ Even listening to music at school was intended to illustrate knowledge: "It was important to logically and clearly convey the knowledge of music."12

New untraditional qualities characterised the music syllabus for primary schools prepared by Eirimas Velička, ${ }^{13}$ as did his textbooks Muzika [Music]. ${ }^{14}$

${ }^{8}$ V. Tarnauskaitè-Palubinskiene, 'Eduardas Balčytis. Kompleksinio muzikinio ugdymo koncepcija' [The conception of complex music education], in R. Vitkauskas (ed.), Bendrasis muzikinis ugdymas Lietuvoje: raida ir kryptys [The general music education in Lithuania: Development and trends], Vilnius, Edukologija, 2012, pp. 63-72.

9 V. Krakauskaite, Pradines mokyklos programos: Muzika [Elementary School Programs: Music], Kaunas, Šviesa,1992, pp. 139-160.

${ }^{10}$ V. Krakauskaité, Lakštutè. Muzikos vadovèliai I-IV klasèms [Nightingale. Music textbooks for the $1^{\text {st }}$ to $4^{\text {th }}$ grade], Kaunas, Šviesa, 1995, 1996, 2000.

${ }^{11}$ J. Abramauskiené, 'Vidos Krakauskaitès muzikos mokymo sistema' [Vida Krakauskaite’s musical upbringing system], in R. Vitkauskas (ed.), Bendrasis muzikinis ugdymas Lietuvoje: raida ir kryptys [The general music education in Lithuania: Development and trends], Vilnius, Edukologija, 2012, pp. 50-63.

${ }_{12}$ V. Krakauskaite, Muzika mažiesiems [Music for kids], Kaunas, Šviesa, 1994.

${ }^{13}$ E. Velička, Pradines mokyklos programos: Muzika [Elementary School Programs: Music], Kaunas, Šviesa, 1992, pp. 115-139.

${ }^{14}$ E. Velička, Muzika: I-IV klasiu vadoveliai [Music: Textbooks for the $1^{\text {st }}$ to $4^{\text {th }}$ grade], Kaunas, Šviesa, 1995-1998. 
Velička emphasised the opportunity and necessity of national education through music in particular. The idea was not totally new, but he investigated the issue in depth. The theoretical underpinning of Velička's methodology for primary school pupil music education was based on the characteristics of melodies and rhythms of Lithuanian folk songs. Therefore, teaching focused on singing. "The song is a form of Baltic meditation ... one can argue that the ancestral spirit spoke to us through folk art."15

Like Krakauskaite, Velička devoted great attention to notation in the content of education. He argued "when one lived in the epoch of universal literacy, approaching computer literacy ... total ignorance of notation looked paradoxical." "He criticised the practice of teaching notation based on teaching notes when solmising and playing musical instruments while ignoring the child's experience in intonation and rhythm and proposed distinguishing between teaching melody and rhythm when teaching children notation.

In Velička's music education system, instrumental music was especially important: musical instruments were an effective tool that evoked the interest of primary school children in music. A method used widely by Velička was body percussion. He successfully coped with the problem of musical instruments in schools by introducing a six-hole reed pipe, an instrument for every child. The introduction of the school reed pipe was a significant breakthrough in primary school music education methodology. The reed pipe became an especially favorite instrument used by most primary school teachers in their lessons.

The uniqueness of Velička's system of music education was its ethnic character. Based on ancient Lithuanian folk songs and their rhythms, conditions were created to form a deep sense of ethnic music, and through it, of the ethnic Baltic worldview. This direction in education was reinforced by singing and playing Lithuanian musical instruments and listening to music: all this could define Velička's system as a national music education system. ${ }^{17}$

Velička's music textbooks received positive evaluation from teachers. ${ }^{18}$ Most of them found them appropriate, yet some teachers wanted more variety and proposed to make use of not only folk songs but also contemporary tunes: children at that age preferred joyful music with clear rhythm and dynamic

${ }^{15}$ E. Velička. Garsu ir tylos paslaptys: Muzika I-IV klasèje [Secrets of sounds and silence. Music for $1^{\text {st }}$ to $4^{\text {th }}$ grade], Kaunas, Šviesa, 1995, p. 15.

16 Ibid., p. 61.

${ }^{17}$ K. Barisas, 'Eirimo Veličkos tautinio muzikinio ugdymo sistema' [Eirimas Velička: System of national music education], in R. Vitkauskas (ed.), Bendrasis muzikinis ugdymas Lietuvoje: raida ir kryptys [The general music education in Lithuania: Development and trends], Vilnius, Edukologija, 2012, pp. 192-203.

18 A. Šumskis, 'Bendrojo muzikinio ugdymo problemos švietimo reformos kontekste' [Issues of general music education in the education reform context], in Muzikinis ugdymas: III respublikines mokslines praktines konferencijos pranešimai [Music education: Thesis of Third Republican Scientific Practical Conference], Vilnius, VPU leidykla, 1999, pp. 118-121; J. Abramauskienė, 'Vidos Krakauskaitès muzikos mokymo sistema' [Vida Krakauskaitė music education system], in R. Vitkauskas (ed.), Bendrasis muzikinis ugdymas Lietuvoje: raida ir kryptys [The general music education in Lithuania: Development and trends], Vilnius, Edukologija, 2012, pp. 50-63. 
melodic development. Teachers agreed that folk songs were irreplaceable in education, but the exaggerated prevalence of folklore limited music education with its one-sided content and did not encourage pupils contemporary socialization. Teachers also missed more contemporary teaching forms and methods. ${ }^{19}$ The emergence of such forms was predetermined by the development of integration and creativity in the content and process of education.

Integration provided an opportunity to closely relate artistic education with social and cultural realities of life, provide a holistic understanding of the world, and create context for problem-based education in response to pupils' interests and needs. Education was based on real life and stopped being a field of activity detached from reality. That helped increase motivation for learning, fostered a personal system of values, educated a creative and responsible person with critical thinking skills, and expanded pupils' life experiences and competences. ${ }^{20}$

The initiators of education reform emphasised the special significance of integrated education for work with junior pupils. At that age, pupils were characterised by a holistic understanding of life that was split into specialised areas by differentiated teaching content. Therefore, teachers faced the task of organising the teaching process to comply with the child's homogeneous view of the world and to form a comprehensive picture of people and culture.

Ruta Girdzijauskiene was one of the first educators to develop the idea of integrated teaching in music lessons. In her academic and methodological publications, she revealed that integrated music education could be realised by finding the links between the music content and the traditions of an epoch or a more specific period by applying different methods of interdisciplinary integration, by using teaching materials and tools of other academic subjects in music lessons, and by finding interrelations between musical activities. Girdzijauskiene stressed that it was of primary importance to choose the content of activity that would comply with pupil age, experience, and interests and stimulate their desire to act. ${ }^{21}$

Girdzijauskiene was the first Lithuanian educologist who studied and promoted the development of creativity through musical activity. ${ }^{22}$ Before

19 A. Šumskis, 'Bendrojo muzikinio ugdymo problemos švietimo reformos kontekste' [Problems of music education in the context of education reform], in Muzikinis ugdymas: III respublikines moksliness praktinès konferencijos pranešimai [Music Education: Thesis of Third Republican Scientific Practical Conference], Vilnius, VPU leidykla, 1999, pp. 118-121.

${ }^{20}$ Ž. Jackūnas, 'Meninio ugdymo vieta integruoto mokymo sistemoje' [The place of arts education in the system of integrated teaching], in V. Matonis (ed.), Šiuolaikinès meninio ugdymo koncepcijos [Contemporary concepts of arts education], Vilnius, Enciklopedija, 2000, pp. 183-191.

${ }^{21}$ R. Girdzijauskiené, 'Muzikos mokytojų požiūrio i̇ integruotą muzikinį ugdymą pradžios mokykloje ypatumai' [Features of music teachers attitudes towards integrated music education in primary school], Tiltai [Bridges], vol. 11, 2002, pp. 39-45.

${ }^{22}$ R. Girdzijauskiené, 'Jaunesniujų moksleiviụ kūrybiškumo ugdymas muzikos pamokose' [Development of junior school children's creativity in music lessons], Lietuvos mokykla: praeitis, dabartis, ateitis [Lithuanian school: Past, present, future], Klaipeda, Klaipèdos universitetas, 1997, pp. 221-223. 
the late $20^{\text {th }}$ century, there were no direct discussions of creativity in Lithuania, but the content of education in Soviet schools provided modest opportunities for development of children's creative powers. One of the priorities in the reformed Lithuanian school was formulated as "the development of an independent and creative personality, able to maximally unfold their abilities as early as at school." ${ }^{3}$ When studying primary school pupils' creativity through musical activity, Girdzijauskiene noted that each child could creatively express themselves through performing and evaluating music. Even the youngest children were able to express their thoughts, ideas, and feelings with meaning through musical sounds and, thus, experience the joy of creative activity. Girdzijauskienès research confirmed that education of creativity through music was important from an educational viewpoint: the child acquired the opportunity to act in a creative way, s/he actualised the world of her/his feelings, imagination, and life-based and artistic experience. Creative activity developed musical abilities and promoted musical intelligence and musical and artistic thinking. She identified major directions in creativity education accumulation of pupils' musical experience, stimulation of independence in musical activities, and enhancement of the need for creative self-expression. ${ }^{24}$ However, Girdzijauskiene emphasised that the greatest impact on pupil creativity was probably the teacher's personality and a creative style of work. A creative teacher understood the teaching process not merely as the transfer of knowledge, but as a process of education of an independently thinking individual. Pedagogical creativity implied the teacher's ability to organise lessons in an untraditional structure, choose relevant teaching materials and use them in an interesting way, apply various teaching methods, and involve pupils in an active education process. ${ }^{25}$

Even though much had been done during education reform to improve the condition of music teaching in primary schools, many scholars ${ }^{26}$ agreed that primary school remained the weakest link in musical education in Lithuanian schools. Music was still perceived as rather insignificant, even by primary school teachers. This attitude was because of poor musical competence and preparation of primary school teachers: teachers lacked knowledge of music theory and played musical instruments poorly. That resulted in limited use of

${ }^{23}$ Lietuvos švietimo koncepcija [Education concept in Lithuania], Vilnius, Leidybos centras, 1992.

${ }^{24}$ R. Girdzijauskiené, Vaikas. Muzika. Küryba [Child. Music. Creation], Vilnius, Gimtasis žodis, 2003, pp. 58-62.

${ }^{25}$ R. Girdzijauskienè, Jaunesniojo amžiaus vaikų kūrybiškumo ugdymas muzikine veikla [Development of junior school children's creativity in music lessons], Klaipèda, Klaipedos universiteto leidykla, 2004.

${ }^{26}$ R. Jautakyte, 'Muzikinis ugdymas pradinèje mokykloje' [Music education in primary school], Lietuvos mokykla XXI amžiuje: konferencijos medžiaga [Lithuanian school in 21st century: Conference thesis], Klaipeda, Klaipèdos universitetas, 1997, pp. 64-67; A. Šumskis, 'Bendrojo muzikinio ugdymo problemos švietimo reformos kontekste' [Issues of general music education in the education reform context], Muzikinis ugdymas: III respublikines mokslines praktinès konferencijos pranešimai [Music education: Thesis of Third Republican Scientific Practical Conference], Vilnius, VPU leidykla, 1999, pp. 118-121. 
musical instruments and a negative attitude towards music classes. Moreover, at the time, most schools were poorly equipped with technological and musical aids. Researchers concluded that music classes in primary school should be taught by teachers with special music education. Teacher professionalism, personal qualities, and a positive attitude towards music were the best way to bring pupils closer to the values of music. ${ }^{27}$

\section{Conclusion}

From the very start, education reform in Lithuania was seen by the public as a key factor for progress and the basis for all social reforms. In the implementation of education reform, all its integral parts were restructured: goals and objectives, content, and methods. In 1993, the General Curricula were published, which regulated the content of education in comprehensive schools. It was a curriculum for national schools of a different structure based on traditions of democratic countries that replaced mandatory Soviet ideology. Lithuanian ethnic values were enhanced and education content and methods were further improved. Music education content responded to new understandings of the goals of arts education - fostering pupils' creative abilities and skills of artistic expression as well as the education of individuals as cultured users of artistic values. The content of musical education became broader, teaching methods more diverse and flexible, and teaching aids were prepared. In primary schools, two weekly music lessons were introduced and alternative music textbooks were published.

Balčytis, Krakauskaite, and Velička contributed greatly to music education concepts and systems and expanded and enriched the content of music education by bringing music education closer to the needs of contemporary musical culture - the need to listen to and make music. In former Soviet Lithuanian schools, music teaching content was narrow: pupils mainly learnt notation, theory, and singing. After the school reforms, the main characteristic of music teaching in primary schools was complex teaching based on the diversity of musical activities: singing, listening to music, solmisation, rhythmic ear training, and playing musical instruments. The authors of new education concepts and systems emphasised national music education. They evaluated the fact that the unique character of ethnic culture and musicality was expressed through intonation. Therefore, early listening to ethnic music, singing, and introduction of ethnic culture were accentuated, focusing on the dissemination of Lithuanian folk and professional music.

The restructuring of education in the reformed school of Lithuania was also related to the development of integration elements in the content and process of education. Integrated musical education was actualised by establishing

\footnotetext{
${ }^{27}$ R. Jautakyte, 'Muzikinis ugdymas pradinèje mokykloje' [Music education in primary school], Lietuvos mokykla XXI amžiuje: konferencijos medžiaga [Lithuanian school in $21^{\text {st }}$ century: Conference thesis], Klaipeda, Klaipedos universitetas, 1997, pp. 64-67.
} 
links between the content of music and the realities of social and cultural life by applying various interdisciplinary education techniques, using teaching materials and aids from other academic subjects in music lessons, and finding interrelations between musical activities.

One of the most important goals of the reformed school was education of the creative individual. The development of primary school pupil creativity through musical activity was important from an educational viewpoint: upon acquiring the opportunity to act creatively, children actualised their world of feelings, imagination, and life-based and artistic experience. Creative activity developed their musical abilities, musical intelligence, and musical and artistic ways of thinking. Thus, the key directions of creativity development were identified: accumulation of pupils' musical experience, stimulation of independence in musical activity, and encouragement of the need for creative self-expression.

Despite education reforms, primary school remained the weakest link in musical education in Lithuanian schools. Successful implementation of the goals and the content of music education were prevented by poor musical competences of primary school teachers, which resulted in negative view of music lessons by pupils and music teachers. Researchers in the field discussed the need to improve the training of prospective primary school teachers. 